\title{
December 1975 \\ Monthly Highlights for Office of Nuclear Regulatory Research Programs at Oak Ridge National Laboratory
}




\section{DISCLAIMER}

This report was prepared as an account of work sponsored by an agency of the United States Government. Neither the United States Government nor any agency Thereof, nor any of their employees, makes any warranty, express or implied, or assumes any legal liability or responsibility for the accuracy, completeness, or usefulness of any information, apparatus, product, or process disclosed, or represents that its use would not infringe privately owned rights. Reference herein to any specific commercial product, process, or service by trade name, trademark, manufacturer, or otherwise does not necessarily constitute or imply its endorsement, recommendation, or favoring by the United States Government or any agency thereof. The views and opinions of authors expressed herein do not necessarily state or reflect those of the United States Government or any agency thereof. 


\section{DISCLAIMER}

Portions of this document may be illegible in electronic image products. Images are produced from the best available original document. 
Printed in the United States of America. Available from
National Technical Information Scrvice

U.S. Department of Commerce

5285 Port Royal Road, Springfield, Virginia 22161

Price: Printed Copy \$b.UU; Microflche $\$ 2.25$

This report was prepared as an account of work sponsored by the United States Government. Neither the United States nor the Energy Research and Development Administration, nor any of their employees, nor any of their contractors, subcontractors, or their employees, makes any warranty, express or implied, or assumes any legal liability or responsibility for the accuracy, completeness or usefulness of any information, apparatus, product or process disclosed, or represents that its use would not infringe privately owned rights. 
Contract No. W-7405-eng-26

DECEMBER 1975

MONTHLY HIGHLIGHTS

FOR

OFFICE OF NUCLEAR REGULATORY RESEARCH PROGRAMS

AT

OAK RIDGE NATTONAL LABORATORY

Compiled by

Gordon G. Fee

DECEMBER 1975

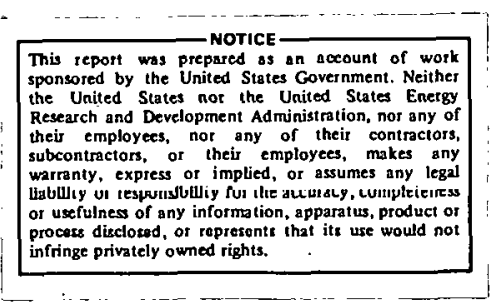

OAK RIDGE NATIONAL LABORATORY

Oak Ridge, Tennessee 37830

operated by

UNION CARBIDE CORPORATION

for the

UNITED STATES

ENERGY RESEARCH AND DEVELOPMENT ADMINISTRATION 
THIS PAGE

\section{WAS INTENTIONALLY \\ LEFT BLANK}


$\underline{\text { Page }}$

HEAVY SECTION STEEL TECHNOLOGY PROGRAM................ 1

FISSION PRODUCT BETA AND GAMMA ENERGY RELEASE........... 5

LOCA RELEASE FROM LWR FUEL.................... 7

MULTIROD BURST TESTS......................... 8

NUCLEAR SAFETY INFORMATION CENTER................. 11

PWR BLOW DOWN HEAT TRANSFER-SEPARATE EFFECTS............ 13

ZIRCALOY FUEL CLADDING COLLAPSE STUDIES.............. 17

ZIRCONIUM METAL-WATER OXIDATION KINETICS.............. 18

AEROSOL RELEASE AND TRANSPORT FROM LMFBR FUEL.............. 19

HTGR SAFETY ANALYSIS AND RESEARCH................. 21

DESIGN CRITERIA FOR PIPING AND NOZZLES.............. 23 
PROGRAM TITLE: Heavy Section Steel Technology Program

PROGRAM MANAGER: G. D. Whitman

ACTIVITY NUMBER: 408911901 (189a No. B0119)

\section{TECHNICAL HIGHLIGHTS}

Task 1: Program Administration - A monthly program review was held for C. Z. Serpan and E. K. Lynn on December 10 and 11 .

The remaining program steel must be removed from the Gaseous Diffusion Plant storage area; therefore, provisions have been made to store all of the HSST program materials in the Y-12 Plant near Bldg. 9204-1.

Task 2: Fracture Mechanics and Analysis - Marc Analysis Research Corporation submitted a draft report, Three-Dimensional Elastic-Plastic Stress and Strain Analysis for Fracture Mechanics: Complex Geometries, on the analysis of an HSST intermediate pressure vessel with an interior flaw at a nozzle intersection. Agreement with experimental data in the region of the flaw was unconservative.

The influence of stress relief temperature on HSST plate 02 material at four temperatures $\left[621,638,654\right.$ and $671^{\circ} \mathrm{C}\left(1150,1180,1210\right.$ and $\left.\left.1240^{\circ} \mathrm{F}\right)\right]$ for $80 \mathrm{hrs}\left(96 \mathrm{hr}\right.$ at $671^{\circ} \mathrm{C}$ ) and a cooling rate range of 79 to $83^{\circ} \mathrm{C} / \mathrm{hr}$ to $316^{\circ} \mathrm{C}$ has been investigated with miniature tensile and Charpy-V specimens. These data indicate that the rate of reduction in mechanical properties increases between the 654 and $671^{\circ} \mathrm{C}$ stress relief temperatures.

Task 3: Fatigue Crack Growth - Testing was completed on the two A533 plate specimens in a PWR environment at Westinghouse Electric Corporation. Specimen 04A-1.02. was tested at $I \mathrm{cpm}$ at an $R$ ralio of 0.7 and specimen $02 \mathrm{~GB}-4$ was tested at $0.1 \mathrm{cpm}$ at an $\mathrm{R}$ ratio of 0.7 . Severe crack branching occurred early in the testing of specimen $02 \mathrm{~GB}-4$ so only limited data were obtained. Those data obtained from the specimens were consistent with previously obtained data.

Testing was begun on two new specimens. Specimen 02GB-7 from HSST plate 02 is heing tested at $0.1 \mathrm{cpm}$ with an $R$ ratiu of 0.2 . The second specimen, FLA-1, is made of A508 forging material and is being tested at 1 cpm with an $R$ ratio of 0.7 . 
The eleven statically loaded $1 \mathrm{~T}$-WOL spectmens undergoing long time $\mathrm{K}_{\mathrm{ISCC}}$ testing at $\mathrm{K}$ levels from $88-110 \mathrm{MN} / \mathrm{m}^{3 / 2}(80-100 \mathrm{ksi} \sqrt{\mathrm{in} .})$ were removed from the chambers and inspected. No crack growth was found after 5000 hours. The specimens have been returned to the chambers for further testing.

Task 4: Irradiation Effects - The dynamic testing of the five remaining 4T-CT specimens at Westinghouse Electric Corporation has been completed. A summary of results is as follows.

\begin{tabular}{|c|c|c|c|c|}
\hline \multirow{2}{*}{ Specimen } & \multicolumn{2}{|c|}{$\begin{array}{c}\text { Test } \\
\text { Temperature }\end{array}$} & \multicolumn{2}{|c|}{$\mathrm{K}_{\mathrm{ID}}$} \\
\hline & ${ }^{\circ} \mathrm{C}$ & ${ }^{\circ} \mathrm{F}$ & $\mathrm{MN} / \mathrm{m}^{3 / 2}$ & $\mathrm{Ks} 1 \sqrt{\mathrm{in} .}$ \\
\hline W583 (RW) & 138 & 280 & 167 & 152 \\
\hline 02GA441 (WR) & 143 & 290 & 282 & 257 \\
\hline 02GA442 (WR) & 121 & 250 & 142 & 129 \\
\hline Weld & 38 & 100 & 104 & 95 \\
\hline Weld & 74 & 165 & 220 & $>200$ \\
\hline
\end{tabular}

The change in specimen material in the second series 4'I'-C'I' irradiations has required changes in the small specimen capsules which fit in the pinholes and slots of the $4 \mathrm{~T}=\mathrm{CT}$ specimens. Pinhole capsule.s are being fabricated and the slot capsule is being redesigned. These changes were required to accommodate $0.5 \mathrm{~T}$ in place of $0.394 \mathrm{~T}$ compact tension specimens. Fabrication of supjort structurcs for the BSR, utilities, capsule parts, and instrumentation is lil progress.

specimen design for the compact tenaion epecimens has been revised as necessary, to provide for load-line displacement measurements thereby permitting $\mathrm{J}$-integral analysis on the $4 \mathrm{~T}, 1.6 \mathrm{~T}, 0.8 \mathrm{~T}$, and $0.5 \mathrm{~T}$ compact tension specimens.

During this report period a meeting was held to discuss the feasibility of using the high-vacuum, electron-beam process for fabrication of composite compact tension specimens from irradiated materials. After much discussion, we concluded that although this process was probably 
ideal for this application, that the costs of obtaining and/or setting up an EB welding system in a hot-cell would be prohibitive.

A composite $2 \mathrm{~T}$ compact tension specimen is presently being machined. This specimen, which is made up of three pieces joined by dovetails, will be used in comparison tests with a standard single-piece $2 \mathrm{~T}$ specimen.

Task 5: Simulated Service Testing - The fabrication of the vessel test support structure and enclosure for the pneumatic test V-7A was completed. Instrumentation plans previously completed are being revised as necessary to allow for installation of a leak-inhibiting device on the inside surface of $\mathrm{V}-7 \mathrm{~A}$ in the area of the prepared flaw. Several conceptual designs of the device are being considered with the view of adopting a reliable concept that can quickly be developed, designed, and fabricated.

The results of a RELAP-4 calculation by ANC of a PWR blowdown were compared with depressurization rates previously estimated at ORNL. The simplified ORNL calculations agree with the ANC results. In the time span of interest in crack propagation and arrest the pressure drop in a cracked PWR pressure vessel is insignificant.

Task 6: Thermal Shock - The second thermal shock experiment (TSE-2) was conducted on December 12, 1975. The initial flaw was an axially oriented semicircular crack about $0.75 \mathrm{in}$. deep and was located at the horizontal midplane of the specimen. Initial temperatures were $289^{\circ} \mathrm{C}$ $\left(552^{\circ} \mathrm{F}\right)$ and $-23^{\circ} \mathrm{C}\left(-9.5^{\circ} \mathrm{F}\right)$ for the test specimen and sink, respectively. Output from acoustic emission and strain gages located in the expected path of crack propagation indicated that the flaw extended along the surface, the firet.indication being at $36 \mathrm{sec}$ and a second at $86 \mathrm{sec}$. Visual observation confirmed the propagation and indicated that the final crack length was about 6 in.

More extensive temperature measurements during the second test indicate greater quenching asymmetry than previously thought to exist. Plans are under way to remedy the situation prior to future testing. The degree of asymmetry experienced in TSE-1 and -2 was not excessive for these particular experiments but could be for experiments involving longer and/or deeper cracks. 
Two 1-in.-diam cores were trepanned from TSV-1 for closer examination of the flaw following TSE-1. Metallographic observations of the cores indicate that the flaw propagated a very short distance (0.04-0.07 in.). It is tentatively concluded that this propagation occurred very early in the thermal shock and is attributed to the existence of EB weld-induced residual stresses.

Task 7: Reheat Cracking - The examination of the heat-affected zone (HAZ) from intermediate test vessel (ITV) No. 4 is continuing. Grain boundary decohesions have been observed in specimen number BlJ. This is the first incidence of "cracking" that has been observed in the ITV No. 4 HAZ . 
PROGRAM TITLE: Fission Product Beta and Gamma Energy Release

PROGRAM MANAGERS: R. W. Peelle and J. K. Dickens

ACTIVITY NUMBER: 408909501 (189a Number B0095)

\section{TECHNICAL HIGHLIGHTS}

The major emphasis this month was on the completion of the data reduction for the first beta-ray data set and the preparation of our report to the meeting of the Decay Heat Review Group on December 18, 1975. As might be expected, several problems associated with beta-ray data accumulation and reduction became better defined during the final stages of data reduction.

As mentioned last month, the covers on the sample holders used were too thick; several new models with thin "windows" were prepared during the month and will be tested during January. In addition, it appears necessary to review carefully the conversion electron branching ratios of our standard sources. This will be done both via literature searches and through our own new measurements. For the latter purpose we are using the $10 \mathrm{cc}$ intrinsic Ge detector purchased in 1974 as one of the possible detectors for the beta-ray decay heat measurement. This detector was made to work satisfactorily during November and is now being calibrated for both gamma-ray and beta-ray response. Preliminary measurements indicate that the response to monoenergetic beta rays is much more complicated than had originally been anticipated, and more complicated than the response for the two-crystal scintillation detector used in the first beta-ray data accumulation run of October. It now appears that the better detector is the scintillation system being used. However, 
the resolution of the intrinsic Ge system to monoenergetic beta rays is much better than that of the scintillator and may well be used to locate and identify conversion electrons having $E_{\beta}>100 \mathrm{keV}$ once the detector response has been adequately measured. To assist in this calibration, additional sources have been fabricated locally and are being studied. At the end of the month a Quick Look Report on Intermediate.Accuracy Spectroscopic Measurements of Decay Heat for Thermal-Neutron Induced Fission of ${ }^{235} \mathrm{U}$ was transmitted to NRC (ma1led 12/24), completing Buff Book. milestone number 28021 . 
PROGRAM TITLE: Fission Product Release from LWR Fuel

PROGRAM MANAGER: A. P. Malinauskas

ACTIVITY NUMBER: 408912701 (189a B0127)

TECHNICAL HIGHLIGHTS:

No progress to report this month. 
PROGRAM TITLE: Multirod Burst Tests

PROGRAM MANAGER: R. H. Chapman

ACTIVITY NUMBER: 408912001 (189a No. B0120)

TECHNICAL HIGHLIGHTS:

On December 2, E. D. Hindle, of the UKAEA (Springlield) Reactor Fuel Element Laboratories, visited ORNL for discussions on cladding behavior. We presented details of the MRBT program and discussed the results of our preliminary findings from prototype simulator tests. Hind 10 and his associaces have cunducted a number of single-rod burst tests, using direct (resistance) heating of the Zircaloy tube. They also found deformation to be unusually sensitive to small temperature differences in and near the $\alpha-t o-\beta$ transition.

On December 4 and 5, J. L. Larson and E. E. Burdick, of Aerojet Nuclear Company, visited ORNL to discuss the MRBT program and how it related to their in-reactor, fuel-behavior tests. The diccussions were very helpful to both organizations; MRBT personnel will visit the ANC test facilities in the spring to continue this useful exchange of Information.

Heater delivery continues to be a problem; acceptance inspection was performed on the 13 SEMCO heaters recelved in late November. Although only one of this group met the purchase order requirements on temperature uniformity, we agreed to accept an additional seven heaters as being of potential use in the test program. We have now received a total of 30 heaters from SEMCO, of which seven met the purchase order requirements; an additional seven were purchased as being of potential use, and 16 were rejected. (We also purchased 12 of the rejected 16 as development healei's for test and evaluation.) The abnormally high rejertion rate has caused a financial burden on the manufacturer, creacting cunsiderable rcluctance to accept the originally agreed-upon purchase price for the 40 heaters under option. A SEMCO representative will visit ORNL the week of January 5 to discuss the techical and contractural difficulties. Until these matters are resolved, we are unable to estimate future delivery schedules. 
It appears that late January or early February is the earliest we can expect the next delivery of heaters to complete the initial order of 20 . No additional heaters were received from RAMA.

Delivery of tantalum sheathed thermocouples also continues to be a problem. We have outstanding purchase orders with SEMCO for ten type $S$ and 95 type $K$.thermocouples. The type $S$ and 45 of the type $K$ thermocouples were scheduled for delivery last March 20 and the 50 additional type $K$ assemblies for delivery on December 1; of these, we have recefved to date 28 type $K$ and four type $S$. Although shipment of the remaining thermocouples was promised for December 23, none were received by the end of December. High temperature evaluation and calfbration was initiated on representative samples of the two types of thermocouples.

We were successful in spot welding four type $\mathrm{K}$ thermocouples (two with Ta sheath and two with nickel-plated stainless-steel sheath) in a prototype simulator (PS-15) tube, using the tools and fixtures developed for this purpose. Following thermocouple attachment, a grooved heater was inserted in the simulator. The two Ta sheathed thermocouples broke and had to be rewelded; burst testing of this prototype simulator (the first to include inside thermocouples) should establish feasibility of this thermometric concept.

Analysis of the temperature data obtained from the bare heater tests conducted last month revealed anomolies that are difficult to resolve. We reassembled heater No. 2828005 into a bare heater test configuration and repeated the tests; the data are not yet analyzed.

We fabricated and tested prototype simulator PS-15, using heater No. 2828006, to explore the unusual behavior found in the two simulators (PS-12 and PS-14) tested previously with this heater. This heater was grooved and plasma spray coated prior to use in PS-12; the coating appeared to be in good condition after that test, and the heater was retested in PS-14. The condition of the coating was poor (powder-like and easy to rub off) after this test; the spray coating was removed (by brisk wiping with paper towels) before the heater was assembled in PS-15 for subsequent testing. Handling of the simulator prior to testing caused one of the tantalum sheathed thermocouples to break at the point 
where the cold-end connector is attached; the test was continued without benefit of the thermocouple. Initial conditions for testing this simulator (PS-15) were the same as the prevlous tests (PS-12 and PS-14) with this heater. Results from this test are not yet available.

A11 the burst tests conducted thus far have been pressurized [at approximately $\left.343^{\circ} \mathrm{C}\left(650^{\circ} \mathrm{F}\right)\right]$ such that the maximum pressure during the transient will be near $6895 \mathrm{kPa}$ (1000 ps1). After attaining a maximum value, the pressure decreases during the test (due to deformation) until rupture occurs, usually in the range of $5723-5998 \mathrm{kPa}$ ( $830-870 \mathrm{psi}$ ) for these initial conditions. Prototype simulator PS-16 was fabricated, using SEMCO heater No. 2828005, for testing at much higher pressure. The simulator end seals apparently leaked during the initial portion of the transient, and the test was aborted. Disassembly of the simulator failed to reveal an obvious cause for the unusual behavior. Data obtained from this simulator are not yet available for analysis.

Simulator PS-17 was fabricated (with SEMCO heater No. 2828005) and tested at the same inftial conditions used for PS-16. The simulator was pressurized with helium to approximately $13275 \mathrm{kPa}$ ( ( $1925 \mathrm{psi})$ at $345^{\circ} \mathrm{C}$ $\left(\sim 655^{\circ} \mathrm{F}\right)$ and isolated from the supply system. The pressure slowly increased during the transient to about $14030 \mathrm{kPa}$ (2035 psi) then decreased rapidly during deformation; rupture occurred at a pressure of about $12135 \mathrm{kPa}(1760 \mathrm{psi})$ and at a temperature of approximately $760^{\circ} \mathrm{C}$ $\left(1400^{\circ} \mathrm{F}\right)$.

The last five drawings for the MRBT test facility instrumentation and controls system were issued to the construction forces for installation of the equipment. Construction of the facility continues to proceed slowly to minimize interference with checkout and test schedules of the THTF. 
PROGRAM TITLE: Nuclear Safety Information Center

PROGRAM MANAGER: William B. Cottrell

ACTIVITY NUMBER: 408912601 (189a No. B0126)

\section{TECHNICAL HIGHLIGHTS:}

During the month of December the staff of the Nuclear Safety Information Center (a) processed 853 documents, (b) responded to 83 inquiries (of which 53. involved the technical staff), (c) made 31 computer searches (of which 2 involved payment), (d) attended 1 meeting, and (e) spoke at 2 seminars. At both of these seminars, sponsored by ORAU, nuclear safety issues were discussed and NSIC and Nuclear Safety brochures were distributed. In addition, Design Data Sheets were prepared on the two-unit Atlantic Generating Station.

Indexed bibliographies of each of two shipments of ACRS reports were prepared this month. The first included 101 documents and the second, 108 documents. Two NSIC reports, ORNL-NSIC-120 "Annotated Bibliography of Hydrogen Considerations in Light-Water-Power Reactors" and ORNL-NSIC-121 "Reactor Operating Experiences 1972-1974," are in reproduction and should be distributed in January. Two other reports, ORNL-NSIC-118 "Siting of Nuclear Facilities, Selections from Nuclear Safety," and ORNL-NSIC-123 "Nuclear Power: Accident Probabilities, Risks, and Benefits; A Bibliography," are now in composition. Work is underway on several other reports, including "A Bibliography of LMFBR Safety" which because of its size will be prepared in two volumes and the annual index of Nuclear Safety which this year will encompass Volume 11 through Volume 16. 
As of the end of September, notices were sent to all former SDI (Selective Dissemination of Information) recipients advising them of the availability of SDI under the recently implemented cost recovery policy. As expected, the immediate response was greater from those who are entitled to this service for free (1.e., primarily NRC and ERDA contractors) than from others who have to pay. During the month of December, 6 of the former and 13 of the latter (totaling \$2201) were added to the SDI distribution list and requests are still coming in steadily. These 19 latest users increase our total number of SDI reciplents to 371 (exclusive of some trial usage), including 38 subscribers who have pald a tolial of $\$ 7837$.

During the month we have recelved 5 Japanese nuclear safety reports to review in order to assess the merits of an English translation. Our assessment of these documents is contained in two letters dated December 9 and 23 , respectively.

Nuclear Safety $17(1)$ is at the printers with distribution expected by the end of January. All technlcal asticles for Nuclear Safoty. 17(2) have been submitted to NRC and ERDA for review, while internal and peer review has been completed for most of the articles in Nuclear Safety 17(3), and manuscript for a few articles for Nucleur: Süfety $17(4)$ are in hand. 
PROGRAM TITLE: PWR Blowdown Heat Transfer-Separate Effects

PROGRAM MANAGER: D. G. Thomas

Activity Number: 408912501 (189a No. B0125)

TECHNICAL HIGHLIGHTS:

Task 1. The second production heater to be tested in the FCTF has undergone three blowdowns and $18.8 \mathrm{hr}$ of operation. The last blowdown was from a power level of $144 \mathrm{~kW}$, rather than the normal value of $122 \mathrm{~kW}$, to determine if a difference in time to $\mathrm{CHF}$ resulted. After $10.4 \mathrm{hr}$ at full power, the heater remains in good condition. The results of the three blowdowns will be reported next month.

Task 2. Tuning of the RELAP4 loop transient model continued using data from isothermal tests 021 and 023 . The base model to be used for pretest prediction of test 100 was assembled.

The first section (ORINC) of the inverse code package was run with input data from the Dry Run Commitment No. 4 Transient. A new and faster solution technique was developed which improved run time by a factor of 5 .

The operator's log program for the heated rod tests has been modified and operationally verified. Complete verification cannot be accomplished until all the instrumentation has been verified and the "loop has been operated with rod power to obtain test data.' A special program was written to locate the position of the rod thermocouples using data taken during a cold water fill of the test section. This test did not provide the information about rod thermocouple positions because of the small differential temperature $\left(1.5\right.$ to $\left.3.5^{\circ} \mathrm{C}\right)$ between the rods and the cold water. The same procedure is to be attempted using hot water to obtain a larger differential temperature. 
The Engineering Unit conversion code was modified to handle the channel allocations for the THTF with the rod bundle installed. Further modifications are necessary to allow for calibrated engineering unit readings to be output for the spool piece drag disks.

The Statistical Analysis code was modified to allow for use on the digitized analog tape unit data. Previously no code was available for such analysis.

Task 3. During the month of December, the installation and verif1cation of most of the remaining components were completed and the facility prepared for cold and hot operations.

The purpose of the cold runs is to tune the primary control valves and generally test the operating capability of the facility. The hot runs are planned to final tune the control valves, principally $\mathrm{HCV}-2$, FCV-1, and FCV-18. During the hot runs, data will be recorded as required hy .Tnhn Sheppard.

The turbine meter instrument spool pieces were removed and new bearings (sàmé as before) lustalled in all metcro.

All densitometers have been refitted with larger magnetic shielding. One is still out of the loop; the remaining three will be examined for vibration effects during the cold and hul ruins.

All loop piping, flanges, etc., as directed by the facility preparation procedure, have been retorqued and the system pressurized fur leak checks.

The rod seal coolant system, including the air blower, the outer seal circulating system, and the inner seal circulating system, was installed and the operation verified. 
Final tuning of the secondary coolant system was started. The major items remaining include the primary heat exchangers A, B, C, and D. Some problems are being experienced in the low flow regions of all exchangers. The sizing of valves for HXC's $H \& D$ are being reexamined.

The installation of the dc power system was completed and checkout started. Some minor items remain, as well as one major, the crowbar system. In preparing for this check, the resistance of the generators was measured; all read low. A hand crank, 500 volt, megger showed generator No. 9 to have a complete short; the others were low. Visual inspection showed the insulation of all generators in bad need of repair. General Electric, Westinghouse, and National Coil representatives inspected the meachines and advised against running until they have been cleaned and the insulation repaired. Each company has been asked to submit a bid on this repair. Repair should begin the second week of. January.

Also remaining in the $\mathrm{dc}$ system are the ground detectors. These were given closer examination due to the generator problem.

The cooling water to the cables has been running during this month. Flow in some cables has decreased to the point where shutdown occurred; no cables have ruptured. Attempts to increase the flow, short of replacing cables, have failed. The lower limit was readjusted.

Installation and checkout of electrical control circuit was completed. All gamma densitometer detectors were modified to include the additional magnetic shielding.

Task 4. Experiments have been conducted in the air-water loop to test the effectiveness of flow dispersing screens located inside the 
THTF two-phase flow monitoring spool pleces. In all runs, the spool piece was oriented vertically with the turbine upstream of the drag disk. A variety of flow dispersing screens were fabricated for Installation immediately downstream of the turbine housing in order to condition the two-phase flow for the densitometer and drag disk. Experimental results are under review and a design is being prepared for flow dispersers located internally in the THTF spool pieces to compliment the flange dispersers already in use.

Design has been completed for utilization of an ionization chamber as a radiation detector in the gamma densitometers. Prellminary tests of the system will be conducted in the air-water, two-phase flow facility. The ionization chambers are expected to show better stability than the photomultiplier tubes currently being used. If results of tests in the air-water facility are favorable, a design will be considered for incorporating ionization chambers in the THTF gamma densitometers.

Task 5. The manufacturer of thermocouples for bundle 2 continued to experience fabricacion problems and submitted a propooal for providing single-diameter $(0.020-$ in.-OD) in lieu of dual-diameter $(0.040-$ in. to 0.020 -in.-OD) assemblies. After negotiation, an agreement was reached whereby the manufacturer would supply the remaining ( 880 ) assemblies at a reduced cost. To date $\sim 80$ dual-diameter assemblies have been received on this order.

The manufacturer of thermocouples for bundle 3 (backup for bundle 2) has delivered 2250 single-diameter assemblies. Of this shipment, 56 assemblies were tested and shipped to the heater manufacturer for installation in the preproduction heaters for bundle 2 . 
PROGRAM TITLE: Zircaloy Fuel Cladding Collapse Studies

PROGRAM MANAGER: D. O. Hobson

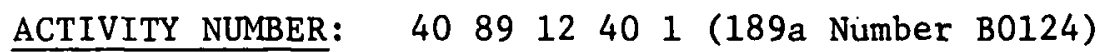

TECHNICAL HIGHLIGHTS:

We have completed the testing called for in the collapse-study test matrix (Level C Milestone, Perform Collapse Tests, 12-15-75E). In addition to the test matrix, further testing has been performed to investigate and correlate the effects of low-temperature anneals on the collapse behavior. Equipment for monitoring creep deformation is being completed and will be installed, with checkout of initial creep tests being completed in January . 
PROGRAM TITLE: Tirconium Metal-Water Oxidation Kinetics

PROGRAM MANAGER: C. J. McHargue

ACTIVITY NUMBER: · 408912801 (189a Number BO128)

TECHNICAL HIGHLIGHTS:

We have completed the experimental phase of the diffusion of oxygen in $8-7$ ircaloy, and we have begun analyzing the isothermal oxidation rate data (Level B Milestone 43072; see also Level C Milestones 43072 and 43181 ). 
PROGRAM TITLE: Aerosol Release and Triansport from LMFBR Fuel

PROGRAM MANAGER: M. H. Fontana

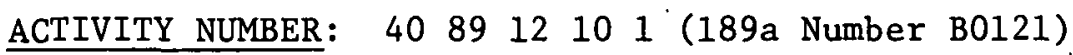

\section{TECHNICAL HIGHLIGHTS:}

\section{Development:}

Preparations and sample assemblies were completed for the January CDV development tests at Arnold Engineering Development Center (AEDC). This series, the next-to-last one, to be conducted during the week of January 5-8 will investigate the effects on aerosol yield of increasing the delay time after preheat allowing increased flattening of the initial temperature profile. In addition, the tests will include increased thermal insulation and replicate runs to demonstrate data reproducibility.

Components for the ORNL CDV system to be used with the CRI-III and FAST facilities have been ordered. Electrical cables and ignitron switches have already been delivered and the capacitors are due in January.

Cold Proof Tests - CRI-II:

After some delays due to holidays and vacations of key craft personnel, assembly of the arc-hearth furnace is continuing. Meanwhile, the CRI-II facility has been prepared to run $\mathrm{U}_{3} \mathrm{O}_{8}$ tests at higher wall temperatures: Pre-test HAARM-1 code calculations indicate that we should expect only minor effects of the increased wall temperature at the levels attainable in these tests.

\section{CRI-III Facility:}

Minor delays have been encountered in the construction of the CRI-III vessel as a result of slower than expected delivery of components. 
Consequently, completion of fabrication and assembly: of this vessel is now projected to be near the end of January. However, this should have no effect on the completion of the entire test facility which is continuing on the present schedule.

NSPP:

During the month of December, the NSPP project has entered into a phase of increased craft activity. The CPFF contractor has been brought on-line and, along with UCCND crafts; has begun facility and building reactivation. This craft activity will be sustained at a high level to complete the facility reactivation this fiscal year.

\section{Bubble Transport:}

The bubble transport test facility is still in des1gn stage. The design of the major component, the vessel itself, has been completed and specifications have been released for solicitation of bids for its construction by outside vendors.

A surplus stainless steel sodium dump tank complete with penetrations, valves, heaters, and some instrumentation has been obtained for use with this facility. 
PROGRAM TITLE: HTGR Safety Analysis and Research

PROGRAM MANAGER: J. P. Sanders

ACTIVITY NUMBER: $\quad \begin{array}{llllll}40 & 89 & 12 & 201 & \text { (189a Number B0122) }\end{array}$

\section{TECHNICAL HIGHLIGHTS:}

General: Code development work continued on the ORTAP, BLAST and ORECA programs. A draft report was received from the University of Tennessee on their steam generator model development work. The report is being reviewed internally.

Core Simulation for Emergency Cooling Analysis: Further work was done on developing the dynamic models for the CAHE and CACT. A series of DBDA and LOMLC accident simulations were run for the Fulton (GASSAR) plant design.

Reheater and Steam Generator Model Development: The routines in BLAST used to determine the thermodynamic transport properties of water were improved. These routines now use the formulations presented in the 1967 ASME steam tables.

Modeling of the FSV steam generator with the BLAST code was initiated. The model will first be compared with the linear model developed by the University of Tennessee and then with dynamic test results from Fort St. Vrain.

Development of the System NSS Simulation Code (ORTAP) from Component Models: Emphasis was placed on documentation of the component models. Calculations for a sample problem to be included in the documentation of the steam generator model (BLAST), which is used in ORTAP, were completed. Computer Code Implementation: The OXIDE-3 computer program was made operational on the IBM 360 system; this program will be executed for 
comparison with output from a modified version of OXIDE-2 that previously had been used at ORNL. Data statements have been added to the TAP. program to initialize all unspecified Fortran variables to zero; this mimics the function of the UNIVAC-1108 system that sets core equal to zero before the program is loaded. This modification of TAP resulted in divide checks (division by zero) on the IBM 360 system. The GAC-version of the CINDA-3G processor for the RECA code is now operational on the IBM system; however, program diagnostics are being generated when the RECGEN output is input to the preprocessor. 
PROGRAM TITLE: Design Criteria for Piping and Nozzles

PROGRAM MANAGER: S. E. Moore

ACTIVITY NUMBER: $\quad \begin{array}{llllll}40 & 89 & 12 & 30 & 1 & \text { (189a No. B0123) }\end{array}$

TECHNICAL HIGHLIGHTS:

Messrs. C. Z. Serpan, Jr. and E. K. Lynn, Metallurgy and Materials Branch, RSR, visited us on Dec, 10, 1975 to review the program. We have met all of our level $B$, and most of our level $C$ committments for the first half of FY-76. 'In several cases we were significantly ahead of schedule, however, we are behind schedule in the publication of several reports on prior work (level $\mathrm{C}$ committments). During the meeting it was agreed to add some new work for the latter half of FY-76, for which adequate funding exists in this year's budget; specifically to issue a report on the experimental stress analysis of a hemispherical shell-radial nozzle model tested earlier at the University of Tennessee, and to conduct empirical combinedloadings studies for ANSI B.6.9 tees using data obtained from 12-in. and 24-in. tees tested earlier for ORNL at Southwest Research Institute and at Combustion Ingineering, Inc.

Code Rules Development: We are continuing work on the development of improved design rules for loadings in the elastic range for isolated and closely-spaced nozzles in reactor pressure vessels. This is a long. term effort because of the large amount of data which must be collected and evaluated. At present the work is being done primarily by J. L. Mershon, consultant to the design criteria program.

Reports on Prior Work: One report in this category was issued this month: ORNL-5044, Vo1. 3, Stress Analyses of Flat Plates with Attached Nozzles, Vol. 3. Experimental Stress Analyses of a Flat Plate with Two Closely Spaced Nozzles of Equal Diameter Attached. This report presents a complete set of test results from an investigation carried out at Auburn University under subcontract to ORNL. Data from these studies will be used to validate computer programs and analytical stress analysis methods, as well as in the development of design rules for closely-spaced nozzles in large diameter pressure vessels. 
Cylindrical Shell Studies: Work is continuing on two projects started last month: (1) the development of a finfte element computer program for the stress analysis of closely spaced nozzles in cylindrical pressure vessels under internal pressure being done at MRI under subcontract, and (2) a finite element parameter study of the stresses at 1solated nozzles in cylindrical pressure vessels being done at ORNL with the assistance of UCC-ND Computer Sciences Division personnel. Very good progress is being made on both studies.

Elbows and Curved Pipe Studies: The cyclic internal pressure fatigue test of a 10 -in ips $90^{\circ}$ long-radius machined elbow is continuing at Combustion Engineering Inc. In Chattanooga.

ANSI B16.9 l'ee Scudies: Wurk was otarted at MRT to prepare a summary report on the elastic response and fatigue tests of five 24-in. ips B16.9 tees that were tested earlier at Combustion Engineering. We expect the report to be completed in final draft form by the end of June 1976. 
Internal Distribution

ORNL/TM-5263

$\begin{aligned} \text { 1. } & \text { J. V. Cathcart } \\ 2 . & \text { R. H. Chapman } \\ 3 . & \text { W. B. Cottrell } \\ 4 . & \text { F. L. Culler } \\ 5 . & \text { D. S. Eaker } \\ 6-10 . & \text { G. G. Fee } \\ 11 . & \text { D. E. Ferguson } \\ 12 . & \text { M. H. Fontana } \\ 13 . & \text { D. O. Hobson } \\ 14 . & \text { H. W. Hoffman } \\ 15 . & \text { P. R. Kasten } \\ 16 . & \text { T. S. Kress } \\ 17 . & \text { R. E. MacPherson } \\ 18 . & \text { F. C. Maienschein }\end{aligned}$

1. J. V. Cathcart

3. W. B. Cottrel1

4. F. L. Culler

5. D. S. Eaker

11. D. E. Ferguson

12. M. H. Fontana

13. D. O. Hobson

14. H. W. Hof fman

18. F. C. Maienschein
19. A. P. Malinauskas/G. W. Parker

20. S. E. Moore

21. R. W. Peelle/J. K. Dickens

22. H. Postma

23. W. R. Ragland

24. J. P. Sanders

25. D. G. Thomas

26. D. B. Trauger

27. G. C. Warlick

28. J. R. Weir

29. G. D. Whitman

30. ORNL Patent Office

31 - 32. Central Reference Section

33. Document Reference

34 - 35. Laboratory Records Department

36. Laboratory Records (RC)

\section{External Distribution}

37 - 38. W. D. Adams, ERDA-Oak Ridge Operations

39. R. T. Curtis, NRC-ONRR

40. E. H. Davidson, NRC-ONRR

41. Director, Reactor Division, ERDA-Oak Ridge Operations

42. W. V. Johnston, NRC-ONRR

43. C. N. Kelber, NRC-ONRR

44. H. J. C. Kouts, NRC-ONRR

45. E. K. Lynn, NRC-ONRR

46. P. G. Norry, NRC-ONRR

47. M, L. Picklesimer, NRC-ONRR

48. D. D. Reiff, NRC-ONRR

49. L. N. Rib, NRC-ONRR

50. R. M. Scroggins, NRC-ONRR

51. C. Z. Serpan, NRC-ONRR

52. L. S. T'ong, NRC-ONRR

53. R. W. Wright, NRC-ONRR

54 - 56. Office of Watar Reactor Rçearch Coordinaliun, ERDA

57. Research and Technical Support Division, ERDA-ORO

58 - 84. Technical Tnfnrmation Center (25 copies, NTIG) 